\title{
As simplificações criminosas do negacionismo da COVID-191
}

\author{
The Criminal Simplifications of COVID-19 Denial \\ Las simplificaciones criminales del negacionismo COVID-19 \\ Jean-Pierre Dupuy \\ Stanford University \\ jpdupuy@stanford.edu
}

\section{Resumo}

Neste artigo, o Professor Jean-Pierre Dupuy busca explorar as dimensões éticas trazidas à tona pelo contexto da pandemia da Covid-19, baseando-se na ideia de que o Sars-Cov2 é eminentemente um vírus moral. 0 pensador francês, inicialmente, desconstrói os argumentos dos negacionistas da pandemia, em particular em relação à gravidade relativa da doença e da supremacia da economia. Em seguida, 0 autor conclui sua reflexão argumentando que a própria ideia de liberdade não é irrestrita, propondo assim uma postura ética necessária a esses tempos, baseada no bom senso e na consciência de que para me proteger do vírus preciso, acima de tudo, proteger 0 outro.

Palavras-chave: Covid-19. Ética. Negacionismo.

\section{Abstract}

In this article, Professor Jean-Pierre Dupuy seeks to explore the ethical dimensions brought to light by the context of the Covid-19 pandemic, based on the idea that Sars-Cov2 is eminently a moral virus. The French thinker initially deconstructs the arguments of pandemic deniers, in particular regarding the relative severity of the disease and the supremacy of the economy. Then, the author concludes his reflection arguing that the very idea of freedom is not unrestricted, thus proposing a necessary ethical posture for today, based on common sense and the awareness that to protect myself from the virus, I must, above all, protect the other.

Keywords: Covid-19. Ethics. Denialism.

\section{Resumen}

En este artículo, el profesor Jean-Pierre Dupuy busca explorar las dimensiones éticas reveladas por el contexto de la pandemia de Covid-19, partiendo de la idea de que el Sars-Cov2 es eminentemente un virus moral. El pensador francés deconstruye inicialmente los argumentos de los negadores de la pandemia, en particular en lo que respecta a la gravedad relativa de la enfermedad y la supremacía de la economía. Luego, el autor concluye su reflexión argumentando que la idea misma de libertad no es irrestricta, proponiendo así una postura ética necesaria para estos tiempos, basada en el sentido común y la conciencia de que para protegerme del virus, debo, sobre todo, proteger al otro.

Palabras-clave: Covid-19. Ética. Negacionismo.

A pandemia da COVID-19 é uma tragédia de escala global. Ninguém esperava, ninguém se preparava para isso. Ninguém sabe como vai evoluir nem se, daqui a um ano, três, ou mesmo mais, estaremos finalmente livres disso.

Essa tragédia afeta todas as nações do mundo, embora em graus variados. Três países preocupam-me especialmente. Em primeiro lugar, o meu país, a França. Também o Brasil, que é o país dos meus filhos e de um neto. E os Estados Unidos da América, especialmente a Califórnia, onde lecionei e pesquisei por 35 anos e onde também tenho contatos íntimos.

10 presente artigo foi apresentado e debatido no $11^{\circ}$ Seminário de Filosofia e Comunicação promovido pela Faculdade Paulus de Tecnologia e Comunicação - Fapcom em maio de 2021. Texto traduzido do francês por Carlos Eduardo Souza Aguiar. 
Não direi nada sobre o Brasil. Em primeiro lugar, porque é o país que me acolhe e devo-lhe o maior respeito. Mas também porque estou muito mal-informado.

Gostaria de contar-lhes sobre a luta que venho conduzindo no meu país há um ano. Já lutei muito no passado contra os chamados negacionistas da mudança climática, essas pessoas que afirmam que a mudança climática é uma farsa ou mistificação inventada para satisfazer obscuros interesses privados; ou os que, embora aceitem a evidência de que a Terra está esquentando, argumentam que os humanos não têm nada que ver com isso. Parece que, diante das consequências cada vez mais visíveis da perturbação do clima do planeta, os céticos do clima estão se tornando cada vez menos ouvidos.

O extraordinário é que vemos as mesmas negações sobre a pandemia atual, já que o mundo inteiro parou de girar por causa dela. Não é no futuro que ocorrerá um desastre. Aqui estamos nós, até o pescoço. Como se fossem cegas, em todo o mundo encontramos pessoas que afirmam (1) que a pandemia não é mais perigosa do que uma pequena gripee (2) que os meios implementados para contê-la, especialmente o fechamento da economia e o sacrifício das liberdades fundamentais, são escandalosamente desproporcionais em comparação com a irrelevância da doença.

Vou mostrar que essas duas afirmações são radicalmente falsas. Mas antes gostaria de denunciar um grotesco erro de lógica cometido pelos negacionistas da Covid-19. Admitamos - o que é obviamente falso - que a pandemia não é muito mortal. Não seria esse o resultado das medidas enérgicas que temos implementado? Em vez de dizer "não é tão grave, portanto as medidas são injustificadas", não deveríamos dizer "se não é mais grave do que o que observamos, é precisamente porque essas medidas foram implementadas"? Para ter certeza, basta se perguntar o que teria acontecido se nada tivesse sido feito para conter a pandemia. Temos todos os motivos para pensar que o número de mortes no mundo teria sido significativamente superior ao atribuído à chamada gripe "espanhola", aquela que assolou as nações no final da Primeira Guerra Mundial, em 1918-1919. O número de mortos é estimado em centenas de milhões.

Porém, tanto a afirmação de que estamos tratando de uma "gripezinha" (1) como a de que a economia e as liberdades são sacrificadas por nada (2) devem ser rejeitadas com firmeza.

Eu começo com (1). Já em maio de 2020, meus colegas da Universidade Stanford sabiam coisas sobre esse vírus, cujo nome ninguém fala - SARS-CoV-2 -, que prenunciavam um futuro muito sombrio.

Aviso: as expressões que usarei dão a entender que o vírus é dotado de intencionalidade, o que obviamente não é. Ele nem mesmo é um ser vivo. Os biólogos se permitem esse tipo de recurso porque têm uma explicação puramente mecanicista por trás dessas metáforas: a seleção natural. O vírus não está vivo, mas anseia pela vida. É o último parasita e precisa de um hospedeiro, um ser verdadeiramente vivo. Esse coronavírus entendeu que ao matar seu hospedeiro, ele se mataria. Buscando maximizar sua taxa de replicação, substitui a letalidade por contágio. ${ }^{2} \mathrm{SARS}-\mathrm{CoV}-2$ é o ápice dessa evolução. Isso se manifesta em uma rara propensão a sofrer mutações - "variantes" - que são menos letais, mas claramente mais contagiosas. Como circulam muito rapidamente, o número de mortes aumenta.

2 Recordo que a taxa de letalidade é o número de mortes em relação ao número de pessoas infectadas - e não em relação à população total. 
Outra característica única da doença, conhecida como COVID-19: mata principalmente os muito idosos. A taxa de letalidade de pacientes com mais de 75 anos é três vezes maior que a de pacientes entre 65 e 74 anos. Daí a tentação abominável em que alguns caem: já que vão morrer de qualquer maneira, não protejamos os velhos dos mais jovens e deixemos que estes vivam e trabalhem como antes.

Muito cedo também se suspeitou que a doença fosse o que se chama de doença autoimune, como a AIDS e a hepatite C. A morte não é o único desfecho trágico desse flagelo. Muitos dos que foram para a terapia intensiva e sobreviveram apresentam sequelas graves que afetam os pulmões, o sistema cardiovascular e o cérebro e se manifestam algum tempo após a alta hospitalar, geralmente após a cura. Os sintomas que podem ser muito debilitantes, como fadiga crônica e problemas respiratórios persistentes, são mal compreendidos e dificilmente reconhecidos pela classe médica. Como permanecem mesmo quando o vírus não está mais presente no corpo, é difícil para o paciente convencer-se de que não é vítima de sua imaginação. Essa situação, entretanto, não é nova. Ocorre quando se está lidando com uma doença autoimune. O assassino não é o vírus, mas o sistema imunológico, que se torna incapaz de cumprir sua função de distinguir entre o eu e o não eu para melhor defender o primeiro contra os ataques do segundo. Os pesquisadores da área médica ainda têm dificuldade em reconhecer que a COVID-19 pertence a essa categoria, preferindo recorrer a eufemismos como "manifestação hiperinflamatória aguda” ou "reação inflamatória desproporcional”. De qualquer forma, esse vírus não apenas mata, mas também pode arruinar sua vida.

Também muito cedo foi estabelecido que nem todas as pessoas e todos os eventos desempenham o mesmo papel na propagação do novo vírus. Entre dezenas de outros, um estudo realizado em Hong Kong entre 23 de janeiro e 28 de abril do ano 2020 concluiu que 20\% dos casos de contaminação foram responsáveis por $80 \%$ das transmissões, e que $70 \%$ dos recém-infectados não transmitiram o vírus para ninguém. Um paciente passou duas semanas no mesmo hospital e infectou 138 pessoas. Esse é chamado de um "superpropagador".

Essa característica é típica de doenças autoimunes. Ela também foi notada rapidamente em relação à AIDS. O paciente considerado "zero", aquele que iniciou a propagação nos Estados Unidos, era um franco-canadense, mordomo de profissão, homossexual que, antes de morrer de sarcoma de Kaposi, se estima ter tido cerca de 2.500 parceiros sexuais. A ideia de lidar com esses superpropagadores como uma prioridade foi considerada, mas logo se deparou com um problema ético aparentemente intransponível. Essa política parecia recompensar a promiscuidade sexual. Assim, daríamos drogas raras e caras a indivíduos considerados imorais, como esse mordomo ou prostitutas pobres que trabalham intensamente, e abandonaríamos os numerosos casos de indivíduos cujas "falhas" eram ocasionais? Nós não decidimos. Ajudar apenas os primeiros também significava estigmatizá-los.

O caso do coronavírus é obviamente muito diferente. Provavelmente, muitos dos superpropagadores nem mesmo estão doentes. Eles são portadores assintomáticos. Apenas testes completos iriam identificá-los. Eles só poderiam ser "neutralizados" se colocados em quaren- 
tena, já que não há tratamentos disponíveis. No entanto, o que os torna superpropagadores provavelmente são menos suas características pessoais do que as circunstâncias em que se encontram ou o evento do qual estão participando. Por exemplo, as grandes celebrações de liberdade de movimento e ação retomadas, como consequência do primeiro desconfinamento, reuniram em várias partes da França multidões consideráveis, muitas vezes pessoas jovens ou muito jovens, sem máscaras, grudadas umas nas outras, inconscientes do fato de que, ao fazer isso, estavam ajudando a tornar a nação inteira um pequeno mundo pelo qual o vírus poderia viajar no menor tempo possível. Como no caso da AIDS, o governo francês não tem conseguido ir muito longe na repressão a esses grupos. $O$ governo considera que não pode se dar ao luxo de estigmatizar os jovens, como não quis fazer com os homossexuais em uma época em que se acreditava que apenas eles transmitiam AIDS. Os vírus dão boas-vindas a essa procrastinação.

Chego à segunda afirmação dos negacionistas: é um escândalo sacrificar a economia e as liberdades fundamentais por essa "gripezinha".

O que responder em relação a isso? Primeiro, que todos os países que escolheram em um momento ou outro sacrificar a saúde da população à marcha irrestrita da economia produziram carnificina, sem que a economia se beneficiasse disso. A razão é simples: o acúmulo de cadáveres não é bom para o funcionamento das fábricas nem para o consumo das pessoas. Não ativamos uma economia moderna em um cemitério. Os exemplos são muitos: a Suécia e o Reino Unido, que recuaram quando a epidemia saiu do controle. A Espanha, cuja primeira restrição foi um grande sucesso, reabriu suas fronteiras ao turismo no verão de 2020: o vírus se alastrou imediatamente. O mesmo infortúnio aconteceu em Portugal nas férias de Natal de 2020. A ideia de que os governos teriam de encontrar um equilíbrio entre as exigências da economia e as da saúde é falsa. A principal prioridade é a saúde, porque sem ela não há economia.

A questão da liberdade é a que causa mais mal-entendidos e suposições extremas e grotescas, absurdos que beiram o delírio e geram mais violência. Na Itália, o famoso filósofo de esquerda Giorgio Agamben fala de um retorno à barbárie, os intelectuais de extrema esquerda franceses evocam o estado de Leviatã. Nos Estados Unidos, estamos lidando diretamente com nacionalistas, fundamentalistas e outros libertários: eles pertencem à extrema direita. O que mais os distingue dos intelectuais europeus de esquerda ou de extrema esquerda não são as ideias, que são essencialmente as mesmas, é com certeza o visual - na forma de máscaras, balaclavas, coletes à prova de balas, cinturões de soldado, botas pretas de combate - e sobretudo o fato de se manifestarem armados.

Impelidos pela Segunda Emenda, eles entraram legalmente em 30 de abril de 2020 no Capitólio do Estado de Michigan, em Lansing, com seus fuzis de assalto, exigindo a "libertação" de seu estado governado por uma democrata eleita, encorajados em tudo isso pelo Presidente dos Estados Unidos. Pois esta é a liberdade que eles exigiam acima de tudo - a liberdade de pegar o vírus e passá-lo para outras pessoas.

Ainda estávamos sob o comando de Trump - parece que faz um século. Essa chamada epidemia, disseram eles, é uma grande farsa inventada pelos democratas para derrubar Trump e a economia. Os números mentem. Além disso, quando você os examina de per- 
to, percebe que eles não são tão perturbadores. O que o doutor Fauci está fazendo na Casa Branca? É ele quem cria o pânico para estabelecer melhor seu poder. Mas é a liberdade que exigimos, não o medo. A morte faz parte da vida e Jesus é nossa vacina. Nós somos o país da liberdade. Não seremos forçados a usar máscaras, distanciamento social ou confinamento. Se você quer o comunismo, vá para a China. Nossos direitos fundamentais garantidos pela Constituição são sagrados e, mesmo assim, são violados. O trabalho é o instrumento da liberdade e não existe mais.

Da extrema esquerda à extrema direita, o discurso negacionista é essencialmente o mesmo. Portanto, não é a ideologia que o move. Então o que é? Ignorância, estupidez? É como se tivéssemos voltado ao século V a. C., época de Péricles, Tucídides e da Guerra do Peloponeso, quando uma terrível epidemia de peste assolava Atenas. É dessa época que data a palavra epidemia, que significa literalmente acima (epi) do povo (demos). Os gregos da época não tinham a menor ideia do que chamamos de contágio: algo que flui horizontalmente de pessoa para pessoa e todos passam para os outros. Observaram que quando estavam reunidas em um lugar as pessoas tinham maior probabilidade de adoecer, logo deduziram que o mal vinha de cima. Isso tinha que ser algo comum a todos, pois mesmo que nem todos tenham morrido, todos foram atingidos. Portanto, era no ar que respiravam e em seus miasmas que deveria ser encontrada a explicação.

Felizmente, sabemos muito mais. Porém, para falar apenas do meu país, muitas vezes encontramos no supermercado ou no transporte público um desses esquisitos, homem ou mulher, que, sem usar a máscara adequadamente, começa a gritar: "Estamos num país livre! Eu faço o que eu quiser!” Que esses que pretendem dar uma lição prestem atenção! Alguns perderam suas vidas por isso. Mas que liberdade é essa? Podemos admitir que todos sejam livres para se ferir conscientemente, para fumar como uma chaminé, por exemplo, sabendo que o câncer de pulmão está à espreita na próxima esquina. Até mesmo meus compatriotas aprenderam, no entanto, que o tabagismo passivo, aquele que os expõe ao fumo indireto dos fumantes, é perigoso e os fumantes como um todo agora se submetem de bom grado às regras estritas que dividem o espaço entre áreas para fumantes e não fumantes. Por outro lado, quem sabe que tem AIDS e faz sexo sem proteção com um parceiro sem dizer nada é criminoso e seu crime é punível pela lei. E em relação ao SARS-CoV-2?

Tanto as características desse vírus como a tecnologia da máscara, teoricamente, validam as três proposições seguintes:

1. Eu uso minha máscara e o protejo. ${ }^{3}$

2. Você usa sua máscara e me protege.

3. Não sabemos se somos portadores do vírus ou não. ${ }^{4}$

\footnotetext{
3 Máscaras de tecido caseiras não protegem o usuário, mas protegem as pessoas ao redor. As chamadas máscaras "cirúrgicas" protegem os outros e também, em menor medida, o próprio portador da máscara contra projeções vindas de pessoas do lado oposto. Mas não protegem contra a dispersão e inalação de aerossóis que, sabemos hoje (agosto de 2020), têm uma importância maior na circulação do vírus.

4 os portadores assintomáticos representam cerca de $40 \%$ dos casos de contaminação.
} 
Sugiro que quem, sabendo de tudo isso, não usa máscara em lugares onde o bom senso exige (por que é preciso "seguir as instruções" quando um mínimo de bom senso seria suficiente?), seja classificado em situação moral intermediária entre o fumante que fuma em áreas proibidas e o portador de AIDS que voluntariamente infecta seus parceiros.

A configuração lógica e moral do problema é singular, pois ninguém tem interesse particular em proteger os outros, mas depende de todos os outros para a própria proteção. Em um mundo de egoístas racionais, o resultado é a impossibilidade de uma situação global satisfatória. Seria necessário entender que esse vírus age de tal forma que, para se proteger dele, você deve primeiro ser protegido por outras pessoas. É um vírus moral no sentido de que nos leva a pensar nos outros antes de pensar em nós mesmos. E não ouvimos sua lição.

É aqui que reside o crime moral e político cometido pelos intelectuais negacionistas da Europa. Retratar o Estado sob o disfarce do Leviatã, que garante a segurança de seus súditos à custa de sua renúncia à liberdade, é esquecer que, se há servidão, é servidão voluntária. Cabe a esses sujeitos determinar a si mesmos, depois de devidamente informados, as regras de convivência em tempos de pandemia. A menos que sejam suicidas, essas regras não serão fundamentalmente diferentes daquelas que o governo lhes impõe. Mas, obedecendo a si mesmos, eles serão livres. Como escreve Jean-Jacques Rousseau, em seu Contrato social (I, 6): "Cada qual, dando-se por inteiro, a condição é igual para todos". Isso é liberdade, não a liberdade de fazer o que quiser, mas obediência às regras que cada um estabelece para si mesmo.

Ao criticar o poder de modo hiperbólico, por forçar os cidadãos a se submeterem aos seus ditames, os intelectuais negacionistas entregam-se a um jogo perigoso. Incentivam alguns desses cidadãos a renunciar às medidas necessárias, que eles próprios deveriam julgar necessárias, sob o pretexto de que lhes são impostas de cima. Este é o crime deles.

Data do recebimento: $18 / 04 / 2021$

Data do aceite: $11 / 05 / 2021$

Dados do autor:

Jean-Pierre Dupuy

É professor de filosofia e de ciência política da Universidade Stanford (Estados Unidos) e da Polytechnique de Paris (França). Autor de mais de 40 livros articulando ciências cognitivas, epistemologia, cibernética, ética, filosofia social, filosofia política e religião. 